\title{
Çağdaş Ahlaki Doğaüstücülük ve Russ Shafer-Landau ${ }^{1}$ Öz
}

G. E. Moore'un 1903 yılında yayınlanan Principia Ethica adlı çalışmasında savunduğu ahlaki doğaüstücülük, karşılaştığı epistemik ve metafizik eleştirilerle 1960'lı yıllardan başlayarak gözden düşmüştür. 2000'li yıllardan başlayarak yeniden gündeme gelen ahlaki doğaüstücülüğün en önemli savunucularından biri 2003 yılındaki Moral Realism A Defence adlı çalışmasıyla Russ ShaferLandau'dur. $\mathrm{Bu}$ çalışma, öncelikle Moore'un görüşlerine kısaca değinip sonrasında Shafer-Landau'nun ahlaki doğaüstücülüğü nasıl savunduğunu ortaya koymaktadır. Son olarak ise Shafer-Landau'nun görüşlerini değerlendirmektedir.

\section{Anahtar Kelimeler}

Ahlaki Doğaüstücülük, G. E. Moore, Ahlaki Realizm, Russ Shafer-Landau, Normatiflik.

\section{Contemporary Moral Non-Naturalism and Russ Shafer-Landau}

\begin{abstract}
Moral non-naturalism which was defended by G. E. Moore in his Pricipia Ethica at 1903, lose its popularity starting from 1960's due to epistemic and metaphysical criticisms which it faced. Moral non-naturalism came to the fore again starting from 2000's and one of the most important advocate of it is Russ Shafer-Landau with his work named Moral Realism A Defence at 2003. This article, firstly elucidates Moore's thought shortly, then presents Shafer-Landau's defence of moral non-naturalism. Lastly, evaluates Shafer-Landau's thoughts.
\end{abstract}

\section{Keywords}

Moral Non-Naturalism, G. E. Moore, Moral Realism, Russ Shafer-Landau, Normativity.

1 Bu çalışma İstanbul Üniversitesi Sosyal Bilimler Enstitüsü Felsefe Anabilim Dalında Doç. Dr. Abdurrahman Aliy danışmanlığında 2015 yllında tamamlanan İlahi Buyruk Teorisi ve Diğer Ahlaki Realizm Türlerinin Değerlendirilmesi adlı doktora tezinin 146-160. sayfalarından türetilmiştir. 


\section{Giriş}

Ahlak felsefesinin, ahlaki kavramların analiz edilmesi, anlamlarının ortaya çıkarılması, ahlaki yargılarda bulunduğumuzda gerçekte ne yaptığımızın ele alınması, ahlaki özelliklerin doğasının araştırılması gibi ahlaka ilişkin ikinci dereceden sorulara yanıt arayan dalı meta etiktir. Ahlak felsefesinin diğer iki dalı olan normatif etik ve uygulamalı etik, ahlak alanındaki sorunlara normatif yargılarda bulunarak yanıt verirken, meta etik alanında normatif yargılarda bulunulmaz.

Meta etik alanın sorunlarından biri ahlaki özelliklerin gerçekten var olup olmadığı diğeri ise eğer varsa bunların nasıl özellikler olduğudur. Ahlaki realizm, ahlaki özelliklerin insanların zihinsel durumlarından bağımsız dolayısıyla nesnel biçimde var olduğunu savunan görüştür. Ahlaki doğaüstücülük ise ahlaki realizm türlerinden biridir.

Ahlaki doğaüstücülükten ne anlaşılması gerektiğini, bu görüşün nasıl tanımlanması gerektiğini bir sonraki alt başlığa bırakarak öncelikle ahlaki yükümlülüklerimize ilişkin ahlaki yargılarımızın ne gibi işlevleri olduğu ortaya konacaktır. Böylece eğer ahlaki yargılarımıza karşılık gelen ahlaki yükümlülükler nesnel biçimde varsa, bunların hangi özellikleri taşıması gerektiği daha açık kılınmış olacaktır.

\section{a. Ahlaki Özellikler - Diğer Özellikler İlişkisi}

Ahlak dilinin en temel özelliklerinden biri; bir eyleme ya da olguya belirli bir ahlaki özelliği yüklemlediğimizde aynı özelliklere sahip başka bir eylem ya da olguya da aynı ahlaki özelliği yüklemlememiz gerektiği ve bunun hepimiz için mantıksal bir zorunluluk olduğudur. Evrensellik olarak da nitelenebilecek bu özelliğe göre bir X eyleminin Y ahlaki özelliğine sahip olduğu yargısına ulaşmışsam benzer bir X eylemi ile ilgili de Y ahlaki özelliği olduğu yargısına ulaşmalıyım (Pojman ve Fieser 2012: 7).

Çağdaş metafizikteki 'bağımlılık (supervenience)' ilkesi değişik özellik toplulukları arasında olduğu düşünülen mantıksal bir ilişkidir. Buna göre örneğin A özelliği B özelliğine bağımlıdır ancak ve ancak B'de bir değişiklik olmadıkça A'da bir değişiklik olamaz. Burada $\mathrm{B}$ özellik topluluğuna taban özellik, A özellik topluluğuna bağımlı olan özellik denmektedir (Leuenberger 2008: 749). Bu durum, ahlaki özellikler ile diğer (non-moral) özellikler arasında da geçerlidir. Diğer özellikleri açısından birbiriyle özdeş olan iki ayrı eylem ya da olgunun ahlaki özellikleri birbiriyle özdeş olmalıdır.

Ahlak dilinin doğasını, işlevini açıklama iddiasında bulunan bir meta etik teori ahlaki özelliklerle diğer özellikler arasındaki bu mantıksal ilişkinin nereden kaynaklandığını, nasıl korunduğunu açıklamalıdır. Çünkü ahlaki özelliklerle diğer özellikler arasındaki bu ilişkinin kopması durumunda ahlaki yargılarımız keyfi duruma gelir ki bu durum ahlaka ilişkin yaygın günlük uygulamamıza uygun değildir.

Ahlaki özellikler - diğer özellikler ilişkisinin diğer yönü ise belirli ahlaki özellikleri belirli eylem türlerine yüklemlediğimizdir. Örneğin başkasının bir varlığını onun onayı olmadan almak eylemine ahlaki olarak yanlış (yapılmaması gereken) olma özelliğini yüklemlemekteyiz. Benzer biçimde kimi eylem türleri ahlaki olarak doğru 
(yapılması gereken) olma özelliğini alırken, kimi eylem türleri ise ahlaki olarak ne doğru ne yanlış olma özelliğini almaktadırlar. Dolayısıyla ahlakın doğasını açıklama iddiasında bulunan bir meta etik teori neden belirli eylemlere ahlaki olarak doğru, belirli eylemlere ahlaki olarak yanlış, belirli eylemlere ise ahlaki olarak ne doğru ne yanlış olma özelliğini yüklemlediğimizi açılayabilmelidir.

\section{b. Normatiflik}

Ahlaki yargılarımızın ikinci özelliği normatif olmalarıdır. Ahlak alanını gerek felsefenin incelediği diğer çoğu alan gerekse pek çok bilim dalından ayıran yönü, yalnızca dünyanın nasıl olduğu ile değil buna ek olarak dünyanın nasıl olması gerektiği ile de ilgilenmesidir. Ahlak dilinin önemli bir özelliği eylemlerimizi yönlendirici olmasidır.

Bir kişi bir eylemin ahlaki olarak yanlış olduğu yargısında bulunduğunda bu kişinin o eylemi yapmaktan kaçınmak için gerekçesi olduğunu düşünürüz. Benzer biçimde bir kişi bir eylemin ahlaki olarak doğru olduğu yargısında bulunduğunda bu kişinin o eylemi yapmak için gerekçesi olduğunu düşünürüz. Buna ek olarak ahlaki yükümlülüklerin insanlar için oluşturduğu eylem için gerekçeler, kategorik (koşulsuz) olup bütün belirli olgunluğa erişmiş rasyonel bireyler için o kişilerin olumsal arzularından bağımsız olarak geçerlidir. Dahası ahlaki yükümlülüklerin oluşturduğu eylem için gerekçeler kolayca yok sayılamayan güçlü gerekçelerdir.

\section{c. Ahlaki Bilgi}

Ahlaki yargılarımızın bir özelliği de ahlaki bilgidir. Ahlaki bilgiyi şöyle tanımlayabiliriz. Ahlaki yargılarımızdan en azından bir bölümü (hırsızlık yapmanın yanlış olması, insan öldürmenin yanlış olması, adaletli davranmanın doğru olması gibi) ile ilgili insanların büyük çoğunluğu arasında yaygın bir uzlaşım bulunmaktadır ve bu ahlaki önermeleri insanların yaygın biçimde bildiği düşünülmektedir.

Ahlaki yargıların insanlar arasında böyle yaygın olmasının kaynağı ya da nedeni ve eğer bu ahlaki yargılar doğru ise bu ahlaki yargılara karşıllı gelen ahlaki özellikler ya da olgulara epistemik erişimin hangi yollarla olduğu, ahlakın doğasını araştıran görüşlerce açıklanabilmelidirler.

\section{Ahlaki Doğaüstücülük ve G. E. Moore}

Ahlaki doğaüstücülük en genel biçimiyle ahlaki özelliklerin doğaüstü özellikler olması olarak tanımlanır. Böyle bir tanımlamada, kavramın içine doğaüstü özellikler olan teistik özellikler de gireceği için ahlaki teorileri sınıflarken doğaüstücü görüşler içine teolojik iradecilik ya da ilahi buyruk teorisi olarak da adlandırılan teistik meta etik teorilerini alanlar da olmuştur (Fisher 2011: 73-89).

$\mathrm{Bu}$ çalışmada incelenecek doğaüstücü teorileri doğru sınıflayabilmek için, teistik olan doğaüstücü teorilerin varlı̆g 1 da dikkate alınarak, bu tanımı daha da sınırlamak gerekmektedir. Ahlaki doğaüstücülük, ahlakın gerek doğa bilimlerinden 


\section{KOYQl 2018/30}

gerekse teoloji gibi konusu doğaüstü varlık olarak Tanrı olan diğer alanlardan bağımsız olma anlamında özerk olduğunu savunan görüştür. Ahlakın özerk olması, ahlaki özelliklerin ahlaki özellikler dışında özellikler ile analiz edilemeyeceğini, dolayısıyla da ahlaki özelliklerin gerek doğal gerekse doğal olmayan başka özellikler ile tanımlanamayacağını veya bu özelliklere indirgenemeyeceğini savunur (Ridge 2013). Teistik meta etik teorilerde örneğin teolojik iradecilikte ahlaki özelliklerin, tanrısal irade gibi teistik özelliklere indirgendiği düşünülürse, burada incelenecek teistik olmayan dolayısıyla daraltılmış anlamdaki ahlaki doğaüstücülüğü tanımlarken; ahlakın özerk bir alan ve ahlaki özelliklerin başka özelliklere indirgenemez, kendine özgü özellikler olduğunun vurgulanması önemlidir.

Ahlaki doğalcılığın bir türü olan Cornell realizmde ${ }^{2}$ de ahlaki özelliklerin başka özelliklere indirgenemez kendine özgü özellikler olmasının doğalcı ontoloji içinde savunulduğu düşünülürse; ahlaki doğaüstücülüğü tanımlarken; ahlaki özelliklerin yalnızca kendine özgü özellikler olduğu değil doğal olmayan veya doğaüstü özellikler olduğunun belirtilmesi de gereklidir.

Ahlaki doğalcılık türleri içinde Cornell realizm, ahlaki özelliklerin doğal özellikler olduğunu savunması bakımından diğer ahlaki doğalcı teoriler ile ortaktır. Diğer yandan ahlaki özellikleri indirgenemez özellikler olarak değerlendirmesi bakımından diğer ahlaki doğalcı teorilerinden ayrılırken, bu çalışmada inceleyecek olan doğaüstücü ahlak teorileri ile birleşir.

Sonuç olarak burada incelenecek nesnelci bir meta etik teori olarak ahlaki doğaüstücülüğün temel iki tezinden birincisi ahlaki özelliklerin doğal ya da teistik (Wielenberg 2009: 25, 26) başka özelliklere indirgenemeyen kendine özgü özellikler olduğu, ikincisi ise bu özelliklerin doğal olmayan yani doğaüstü özellikler olduğudur. Ahlaki özelliklere ilişkin böyle bir ontoloji sonucunda ortaya çıkan üçüncü iddia ise en azından bazı ahlaki önermelerin delile dayanmaksızın bilinen önermeler olduğudur (Shafer-Landau 2003: 66). Bu yüzden bu tip ahlak teorileri birçok kez sezgicilik olarak da adlandırılmaktadır (McMahan 2000: 92-110).

G. E. Moore, 1903 yılında yayınlanan Principia Ethica adlı çalışmasında ahlaki doğaüstücülüğü savunmuştur. Moore, ahlaki "iyi” kavramının analiz edilemez, basit bir özellik olması gerektiğini, başka özelliklere indirgenemeyeceğini, ortaya koyduğu "açık soru argümanı"na ${ }^{3}$ dayanarak savunmuştur. İndirgemeciliğe böyle karş1 çıktıktan sonra "iyi" kavramıyla ilgili olası iki seçeneğin var olduğunu, bunların ise iyinin bütünüyle anlamsız olması veya basit bir özellik olması olduğunu belirtmiştir (Moore 1903: 15). Moore, birinci seçeneği bütünüyle reddetmiş gözükmektedir (ShaferLandau 2003: 56) ve çabasını ikinci seçeneği savunmak için harcamıştır.

Cornell Realizm, ahlaki doğalcılı̆̆ın bir türü olarak ahlaki özelliklerin doğal özellikler olmasına karşın başka doğal özelliklere indirgenemeyeceğini dolayısıyla başka doğal özellikler ile özdeşleştirilemeyeceğini savunan görüştür. Söz konusu görüş, bu görüşü savunan filozofların bir bölümünün Cornell Universitesi ile yakın ilişkileri nedeniyle bu adla anılmaktadır. Cornell Realizmle ilgili bilgi için bkz. (Sturgeon 1988 ve Miller 2003: 138177).

3 Moore'un açık soru argümanı ve değerlendirilmesi için bkz. (Ferhat Yöney 2015: 257-264). 
Moore, ahlaki özelliklerin, doğal özelliklere yüklemlenmesine karşın, “iyi”nin doğal bir özellik olmadığını belirtir. "İyi”nin diğer doğal özellikler gibi zaman içinde veya zamana bağlı olarak var olduğunu düşünemeyeceğimizi belirtir. "İyi”nin doğal özelliklerin bir parçası olmadığını, ancak doğal özelliklere yüklemlendiğini savunur. Ahlaki özelliklerin doğal özellikler olması durumunda; ahlaki özelliklerin bu nesnelerden alınması durumunda bu nesnelerin var olamayacağını savunur (Moore 1903: 41).

Moore'un açık soru argümanındaki amacı indirgemeci görüşler ve ahlakın özerkliğinin savunulması olduğu için tek amacı doğalcı ahlak görüşlerin eleştirilmesi değildir. Bu nedenle Moore, kitabının 4. bölümü olan "Metafizik Ahlak" bölümünde doğalc1 olmayan diğer doğaüstücü görüşleri de eleştirmiştir. Moore, "Metafizik" olma kavramından doğalcılığın veya doğal olanın tersi dolayısıyla doğal olmayanı anladığını belirtmiştir (Moore 1903: 110, 111). Yani 'Metafizik' kavramını doğal olana karşıt olarak kullanmıştır.

\section{Russ Shafer-Landau ve Günümüzde Ahlaki Doğaüstücülük}

Moore'un görüşleri gerek metafizik gerekse epistemik bir takım eleştirilerle karşı karşıya kalmıştır. Moore'un savunduğu ahlak ontolojisinde ahlaki özellikler, duyular üstü ancak tanımlanamaz bir konumda olmakla eleştirilmiştir. Ayrıca bu ontolojide, ahlaki bilgilere erişim için sezgiler öne sürülürken; bu yönteme gizemli ve anlaşılmaz olduğu eleştirisi getirilmiştir (Hurka 2014).

Ahlaki özelliklerin doğal özellikler olmayıp doğal özelliklere yüklemlendiğini savunmasına karşın bu doğaüstü ahlaki özellikler ile ahlaki özelliklerin yüklemlendiği doğal özellikler arasındaki ontolojik ilişkinin açıklanması Moore'un pozisyonunun karşı karşıya kaldığı diğer ciddi eleştirilerden biridir. Diğer bir eleştiri ise ahlaki özelliklerin bulunduğu doğaüstü alana erişim ile ilgilidir. Bu eleştirilerden dolayıdır ki 1960'lı yıllardan başlayarak Moore'un görüşü yani doğaüstücü ahlak büyük ölçüde felsefi literatürde devre dışı kalmıştır (Hurka 2014).

Ancak 2000’li yıllardan başlayarak ahlaki doğaüstücülük ya da diğer adıyla ahlaki sezgicilik, karşı karşıya kaldığı ve zayıf gözüken yönleri olan ontolojik ve epistemolojik kaygılara verilen yanıtlarla yeniden savunulmaya başlanmıştır (Hurka 2014). Bu çalışmalar içinde en ön plana çıkanlardan biri de Russ Shafer-Landau'nun çalışmalarıdır.

Shafer-Landau, 2003 yılında yayınlanan çalışmasında; hem sistematik bir ahlaki realizm savunması yapmış hem de ahlaki özelliklerin doğaüstü özellikler olan soyut nesneler (abstract object) olduğunu savunmuştur. Ahlaki realizme getirilen metafizik, normatiflik ve epistemoloji ile ilgili eleştirilere yanıtlar sunarken; bunu ahlaki özelliklere ilişkin savunduğu doğaüstücü ontoloji ile yapmaya çalışmıştır.

Ahlaki doğalcılığı eleştiren Shafer-Landau, ahlaki doğaüstücülüğü yani ahlaki özelliklerin doğal özelliklerden ayrı ancak doğal özelliklere bağımlı doğaüstü özellikler topluluğu olduğunu belirtir. Böyle bir yaklaşımın ontolojik olarak kalabalıklaştırma olmadığını savunur. Ahlaki özelliklerin doğal özelliklere indirgenememesiyle ilgili 


\section{$230 \quad$ KOYQl 2018/30}

olarak da; Cornell realizme benzer biçimde biyoloji, tarih gibi alanlara ilişkin özelliklerin fiziksel özelliklerden farklı olduğunu ve bu alanlara ilişkin olguların fizikle ilgili yasalarla kuşatılamayacağını belirtir. $\mathrm{Bu}$ alanlara ilişkin olguların bütünüyle fiziksel kavramlarla açıklanamayacağını savunur. Bu anlamda ahlakın özerkliğini ve özerk olan diğer alanlarla benzer konumda olduğunu belirtir (Shafer-Landau 2003: 72).

Shafer-Landau, önerdiği ahlak ontolojisi için zihin felsefesindeki indirgemeci olmayan teoriler ile paralellikler kurar. Buna göre, zihinsel özellikler fiziksel özellikler ile özdeş değildir ancak fiziksel özelliklerin örneklemeleri ile gerçekleştirilirler. İlgili fiziksel özellikler olmadan, zihinsel özellikler de olmayacaktır (Shafer-Landau 2003: 72, 73), yani zihinsel özellikler fiziksel özelliklere bağımlı olarak vardırlar.

Shafer-Landau, zihin felsefesi ile ilgili bu yaklaşım ile ahlak alanı arasında üç önemli benzerlik olduğunu belirtir. Bunlardan birincisi, zihinsel ve fiziksel özelliklerimizin özdeş olmadığına ilişkin inançtır. Çünkü bu iki farklı kavram aynı anlamlı gözükmemektedir ve ahlaki özelliklerin doğal özelliklere indirgenme girişimlerindeki başarısızlık bunu destekler niteliktedir. Ayrıca, zihinsel özelliklerin çoklu gerçekleştirilebilir veya oluşturulur olması açık bir gerçek olarak görünmektedir. Örneğin bir zihin durumu olarak şaşırma tek bir doğal özellik veya doğal süreç ile değil, çeşitli doğal özellikler veya doğal süreçlerce oluşturulabilmektedir. Benzer biçimde ahlaki iyilik, "en fazla mutluluk" ile oluşturulabilir ancak bu durum, ahlaki iyilik ile en fazla mutluluğun özdeş olduğu anlamına gelmez. Çünkü en fazla mutluluk her zaman ahlaki iyiliği oluşturmayabilir, ayrıca başka özelliklerce de ahlaki iyiliğin oluşturulduğunu görebiliriz (Shafer-Landau 2003: 73, 74).

İkinci olarak; bu ontolojinin cimri olduğunu, kalabalık olmadığını belirtir. Zihin felsefesindeki fizikalist ve indirgemeci olmayan iki görüşten birincisi töz ikiciliği (substance dualism) yani zihin ve maddenin iki ayrı töz olduğu görüşü iken ikinci görüş özellik ikiciliği (property dualism) yani zihinsel özelliklerin doğal özelliklerce oluşturulduğu ve örneklendiği görüşüdür. Bu görüşlerden ilki fiziksel olan dışında ikinci bir temel varlık alanı ortaya koyarak ontolojimizi kalabalıklaştırmaktadır. İkinci görüşe göre ahlaki özellikler doğal özelliklerce oluşturulmaktadır ve doğal özelliklere bağımlı olarak var olurlar. Doğal özellikler ile ahlaki özelliklerin töz ikiciliğindeki gibi iki ayrı töz gibi var olmaları için ise bu iki varlık alanı arasındaki zorunlu ilişki ancak tanrısal özellikler ile kurulabilir ki; bu görüş ilahi buyruk teorisidir. Yani ahlaki özellikleri oluşturan şey bütünüyle ilgili doğal özelliklerdir ve bir ahlaki özellik ancak bu doğal özellikler nedeniyle örneklenmişlerdir (Shafer-Landau 2003: 74, 75).

Üçüncü benzerlik ise zihinsel özellikler ile doğal özellikler arasındaki bağımlılık (supervenience) ilişkisidir. Zihinsel olmayan (non-mental) özellikler açısından özdeş olan iki durum zihinsel özellikleri açısından da özdeş olmak durumundadır. Benzer biçimde bir eylemin veya durumun ahlaki özelliği diğer (nonmoral) özellikleri değişmeden değişemez. Shafer-Landau, ahlaki özelliklerin diğer özelliklere bağımlı olması ve bu özelliklerin denetimi altında olması gerekliliğini kavramsal bir zorunluluk olarak görür (Shafer-Landau 2003: 76, 77).

Shafer-Landau, ahlaki özellikler ile diğer özellikler arasındaki bağımlılık ilişkisi açısından asimetrik bir ilişki olduğunu belirtir. Buna göre, bir ahlaki özelliğin örneklenmesi belirli bir betimsel özelliğin örneklenmiş olmasını gerektirmez; yani 
özdeşlik ilişkisi dışlanır. Ancak tersine doğal özellikler veya diğer (non-moral) özellikler bir eylem veya durumun ahlaki özelliğini belirler (Shafer-Landau 2003: 85).

Ahlaki realizme yönelik olarak ahlaki özellikler ile diğer özellikler arasındaki zorunlu ilişkinin nasıl sağlanacağ 1 eleştirisine ise bilim veya felsefenin diğer alanlarıyla benzerlik kurarak karşılık verir. Benzer bir ilişki, zihin felsefesinde doğal durumlar ile zihinsel durumlar veya kimyada atomla ilgili özellikler ile kimyasal özellikler arasında da vardır. Bu alanlarda da temel özellikler diyebileceğimiz doğal özellikler ve atomla ilgili özelliklerle bu özelliklere bağımlı olan (supervening) özellikler olan zihinsel ve kimyasal özellikler arasında zorunlu bir ilișki vardır. Yani atomlarla ilgili bir özellik belirli bir kimyasal özelliği bir kez oluşturduğunda; atomlarla ilgili aynı özellik aynı kimyasal özelliği hep oluşturmaktadır. Eğer bu alanlarda bu varsayımı kabul ediyor ve gerek zihin gerekse kimya ile ilgili olarak anti realist bir pozisyon belirlemiyorsak benzerini ahlak için de yapabiliriz. Tersine, eğer ahlak alanı ile ilgili anti realist bir pozisyonu seçiyorsak zihin ve kimya alanında da anti realist bir pozisyon izlemeliyiz (Shafer-Landau 2003: 86, 87).

Bağımlılık ilişkisi ile ilgili ikinci konu olan neden belirli eylemlere belirli ahlaki özellikleri yüklemlediğimiz fakat başka eylemlere bu ahlaki özellikleri yüklemlemediğimiz sorunuyla ilgili olarak ise "Klasik Doğalcılık" olarak da adlandırdığı indirgemeci doğalcılığın daha üstün olduğunu ve bu soruya doğrudan bir yanıtı olduğunu belirtir (Shafer-Landau 2003: 90). Doğaüstücülükte ise ahlaki özelliklerin diğer özelliklerce çoklu olarak gerçekleştirildiğini (multiple realizability) savunurken Frank Jackson'ın analitik işlevselciliğine gönderimde bulunur. Jackson'ın ahlaki özelliklere karşılık gelen özelliklerin karmaşık ayırıcı (disjunctive) özellikler olduğu savunmasının doğaüstücü ahlak ontolojisi ile de uyumlu olduğunu savunur. Buna ek olarak sorunun çözülmediğini; karmaşık ayırıcı bir özelliğin ortaya konmasının bu kez de neden başka bir karmaşık ayırıcı özellik değil de bu karmaşık ayırıcı özellik olduğu sorusuna taşınacağını belirtir. Jackson tarzı doğalcılığın doğaüstücülük kadar bu soruna yanıt vermede başarısız olduğunu savunur (Shafer-Landau 2003: 93-95).

Shafer-Landau, neden belirli eylemlere belirli ahlaki özellikleri yüklemlediğimiz sorusuna ancak birinci dereceden ahlaki konuları araştıran normatif etik alanında yapılacak araştırmalar ile yanıt verilebileceğini savunur. Bu sorulara ancak iyilik, eylemlerin doğruluğu, erdem gibi konulardaki yaklaşımlarımız ve bunlarla ilgili normatif etik alanındaki tartışmalarla anlamlı yanıtlar bulunabilir ki; ahlaki doğaüstücülerin ahlaki doğalcılar ve diğer nesnelci görüşü savunanlar kadar bu tartışmalara erişim olanağı vardır. Doğaüstücüler, neden ahlaki özelliklere temel oluşturan özelliklerin tam da bu özellikler olduğuna normatif etik alanındaki çalışmaların sonuçlarından yararlanarak yanıt vermelidirler (Shafer-Landau 2003: 95, 96).

Shafer-Landau, ahlaki özelliklerin bağımsız biçimde nedensel ilişkiye girecek gücü olmadığını, ahlaki özelliklerin nedensel ilişkiye girmeyen soyut nesneler olduğunu belirtir. Ahlaki özelliklerin neye inanmamı gerektiğiyle ilgilenen epistemik olgulara benzediğini belirtir (Shafer-Landau 2006: 226, 227). Bu tanımlama ile hem nedensel ilişkiye giremeyen şeylere ilişkin anti realist tutuma hem de Cornell realistlerin ahlaki özelliklerin nedensel ilişkiye girdiği ve gözlemlerimizin en iyi açıklaması olarak yer 


\section{2

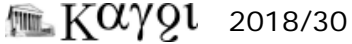

aldığ1 dolayısıyla bu özelliklerin doğal özellikler olması gerektiği düşüncesine karşı çıkar (Shafer-Landau 2003: 108). Nedensel ilişkiye girebilmenin var olmanın ön koşulu olmadığını, dolayısıyla nedensel ilişkiye giremeyen şeylerle ilgili de realist pozisyon benimsenebileceğini savunur.

Doğaüstü ahlaki özellikler, ancak onları oluşturan doğal özelliklerden dolayı veya bu doğal özelliklerin barındırdığı nedensel ilişkiye girme özelliğini alarak nedensel ilişkiye girme gücüne sahip olabilirler (Shafer-Landau 2003: 109). Doğaüstü özellikler ve dolayısıyla soyut nesneler olarak ahlaki özellikler, betimsel değildir yani evrenin veya insan davranışlarının nasıl olduğunu betimlemez veya nasıl olacağına ilişkin öngörülerde bulunmaz. Ahlaki özellikler, yükümlülükleri belirleyici ve insanlara bu yükümlülüklere uygun biçimde eylemler için gerekçeler oluşturma işlevini yerine getirirler (Shafer-Landau 2003: 112).

Shafer-Landau, ahlaki yükümlülüklerin normatifliği konusunda ise ahlaki yükümlülüklerin her zaman insanların arzularıyla ve kişisel çıkarlarıyla uyuşmak zorunda olmadığını; ahlaki yükümlülüklere uygun eylemenin zaman zaman bu arzularımızdan ve çıkarlarımızdan vazgeçmeyi gerektireceğini belirterek; ahlaki özelliklerin eylem için sunduğu gerekçelerin kategorik olması gerektiği görüşünü benimser (Shafer-Landau 2003: 170). Ahlaki özelliklerin eylem için sunduğu kategorik gerekçelerin ise dişsal (extrinsically) yani ahlaki özellikler ile başka özellikler arasındaki bir ilişkiye dayalı olarak değil, kendinden-özsel olarak (intrinsically) var olduğunu savunur (Shafer-Landau 2003: 203, 204). Diğer yandan ahlaki realizm; ahlaki önermelerin insanların durum ve görüşlerinden bağımsız olarak doğruluğuyla ilgili iken; eylem için gerekçelerin pratik akılla ilgili olduğunu belirtir ve ahlaki realizmin ahlakın kategorik olmaması ile de uyumlu olduğunu belirtir (Shafer-Landau 2003: 191).

Shafer-Landau, çalışmasının ahlakın normatifliği ile ilgili bölümünde, ahlakın normatifliğine dayanan ahlaki anti realist eleştirilere yanıt vermiş ve eyleme ilişkin gerekçelerin kategorikliği görüşü ile uyumsuz olan araçsal rasyonalite (instrumental rationalism) ve egoist rasyonalite (rational egoism) teorileriyle karşılaştırmasını yapmıştır. Araçsal rasyonalite ancak ve ancak arzuların bir kişi için eylem için gerekçeler sunabileceğini savunan görüştür. Egoist rasyonalite ise ancak ve ancak kişisel çıkarların kişiye eylem için gerekçeler sunabileceğini savunan pratik akıl teorisidir (Shafer-Landau 2003: 194).

Shafer-Landau, araçsal rasyonalite ve egoist rasyonalite tezlerince ahlakın kategorikliğine karşı getirilen argümanlar da içinde olmak üzere eyleme ilişkin gerekçelerin kategorikliği tezine karşı getirilen, toplam dört tane argümanı ele almış ve bu argümanlara karşı çıkmıştır. Bu dört argümana karş1 getirilecek güçlü itirazların da ahlaki özelliklerin eylem için kategorik gerekçeler sunacağı pozisyonu destekleyecek bağımsız bir argüman oluşturmayacağını da kabul etmiştir (Shafer-Landau 2003: 193209). Sonuç olarak gerek ahlakın kategorikliği gerekse de ahlakın kategorikliğine karşıt olan bu iki görüş olmak üzere toplam üç değişik görüşün felsefi olarak birbirlerinden açık biçimde üstün gözükmediği sonucunu ortaya koymuştur (Shafer-Landau 2003: 209-211).

Shafer-Landau'nun ahlaki özellikler ve bunlardan doğan yükümlülükler ile mantık ve teorik bilginin gerekçelendirilmesi arasında kurduğu benzerliğin ahlaki 
özelliklerin oluşturduğu eylem için gerekçelerin kategorik ve özsel olduğuna ilişkin bir argüman olduğu söylenebilir.

Buna göre kimi özellikler insanlar için kendinde-özsel olarak kategorik normatifliğe sahip olabilirler. Örnek olarak bir kişi güçlü delillere dayanarak bir koşullu önerme ve bu koşullu önermenin ön bileşenini (antecedent) kabul etmiştir. Bu kişi, bu koşullar altında art bileşeni (consequent) kabul etmeyi gerektirecek yeterli gerekçeye sahiptir. Yani bu olgular bu kişiye çıkarları, arzuları ve amaçlarından bağımsız olarak gerekçe sunmaktadır. Bu gerekçeyi kişi kendisi oluşturmamaktadır. Başka bir deyişle bu gerekçe kişinin arzularına ya da çıkarlarına bağlı değildir. Ahlaki özelliklerle bu durum arasında bir paralellik kurulabilir; örneğin herkesin soykırımı kötü olarak saymak ve böyle bir eylemden uzak durmak için gerekçesi vardır (Shafer-Landau 2003: 205-207).

Shafer-Landau mantık yasaları ile ahlak yasaları arasındaki benzerliğe dayalı argümanına da ahlaki bilgiye erişime dayalı bir yorum eklemeyi ihmal etmez. Buna göre gerek mantık yasaları gerekse ahlak yasalarının soyut nesneler olduğu kabul edildiğinde; bu özelliklerin bir kişiye eylem için gerekçe sunması, o kişinin bu olgunun farkında olması, bu ahlaki yasanın doğruluğunu kabullenmesine bağlıdır. Özsel olarak eylem için gerekçe sunabileceği düşünülen bir ahlaki özelliğin geçerliliğini bir kişi sorguladığında, bu yöntem başarısız olmaktadır. Shafer-Landau'nun verdiği örnekle ortaya konursa; bir çocuğa yalnızca haz almak için işkence eden bir adamı ele alalım. $\mathrm{Bu}$ eylemi görüp, bu eylemin kötü bir eylem olduğu sonucuna ulaşmayan veya bunu kabul etmeyen kişinin bu eylemden kaçınmak için kategorik bir gerekçesi olduğunu söylemek zor gözükmektedir (Shafer-Landau 2003: 209, 210).

Yani doğaüstü özellikler olarak ahlaki özelliklerin eylem için gerekçeler sunması bu doğaüstü özelliklere epistemik erişime bağlıdır ki, Shafer-Landau'ya göre araçsal rasyonalite ve egoist rasyonalite bu anlamda herhangi bir sorun yaşamamaktadır. Çünkü gerek kişisel arzular gerekse çıkarlar, yanılabilir olsa da, kişiye epistemik içerik sunabilmektedir. Bu anlamda kimi özelliklerin özsel olarak eylem için gerekçeler sunacağ1 görüşüyle karşıtlık oluşturmaktadırlar ve kategoriklik görüşünden üstün gözükmektedirler (Shafer-Landau 2003: 210, 211).

Shafer-Landau, ahlaki bilgi ile ilgili olarak da hem ahlaki bilginin doğruluğunun gerekçelendirilemeyeceği hem de ahlaki bilgiye erişimin olanağı ile ilgili kuşkucu eleştirilere yine savunduğu doğaüstücü ontoloji içerisinde yanıt vermeye çalışmıştır. Öncelikle, ahlaki önermelerle ilgili kuşkuculuğun ve ahlaki sorunlar konusunda insanlar arasındaki anlaşmazlığın (Shafer-Landau 2006: 219, 220) tek başına ahlaki realizmi reddetmemizi gerektirmediğini belirtir. Ahlaki önermelerin doğruluğunun gerekçelendirilmesi konusunda en azından kimi ahlaki önermelerin kendiliğinden doğru olduğunu savunur. Örneğin, başkalarının acısından haz almanın kötü olması, suçsuz bir kişinin cezalandırılmasının ahlaki olarak yanlış olması gibi önermeler başka bir önermenin temellendirilmesine gerek kalmadan doğrudur. Yani bir kişi bu eylemleri gerçekten anladığında bunları destekleyecek başka inançlara gereksinim duymadan bunların doğru olduğunu düşünebilir (Shafer-Landau 2003: 248). $\mathrm{Bu}$ biçimde hem ahlaki bilginin doğruluğunun gerekçelendirilmesi hem de ahlaki bilgiye erişim sağlanmış olur. 
Ahlaki bilgiye ilişkin kendiliğinden doğru a priori (Shafer-Landau 2006: 212) yolla elde edilen bilgiyi savunan Shafer-Landau, elde edilen bu bilginin doğru olup olmadığı konusunda ise yine bilginin kaynaklarına ilişkin diğer yaklaşımlarla benzerlikler kurar. Algı, hafıza, tanıklık gibi diğer bilgi kaynaklarının da kuşkucu yaklaşımlara karşın bilginin doğruluğunun gerekçelendirilmesinde güvenilebileceğini, dolayısıyla ahlaki bilginin ve a priori bilgi kaynağının diğer gerekçelendirme ve bilgi kaynağı türlerinden farklı değerlendirilmesi konusunda farklı bir tutum takınmamız için bir neden olmadığını savunur (Shafer-Landau 2003: 265).

\section{Russ Shafer-Landau'nun Ahlaki Doğaüstücülükle İlgili Görüşlerinin Değerlendirilmesi}

Shafer-Landau'nun meta etik görüşü ve argümanlarını özetledikten sonra bu görüşler üzerinden ahlaki doğaüstücülüğü değerlendirmek istiyorum. Öncelikle ahlaki özellikler-diğer özellikler ilişkisi açısından değerlendirilirse; Shafer-Landau, ahlaki özellikler ile diğer özellikler arasındaki zorunlu ilişkiyi asimetrik, tek yönlü ilişki olarak; doğaüstü özellikler olan ahlaki özelliklerin doğal özelliklerce oluşturulması olarak ortaya koyar ve özellikle de zihin felsefesi ile benzerlik kurar.

$\mathrm{Bu}$ yolla kurulduğu düşünülen zorunlu ilişkiye getirilen itiraz zihin felsefesi ile ahlak felsefesi arasında kurulan benzerliğin yanlış olduğu yönündedir. Ahlaki özelliklerin diğer özelliklere bağımlı olduğu tezi analitik bir doğru iken; zihinsel özelliklerin diğer özelliklere bağımlı olduğu tezi için aynısını açıkça söylemek güçtür. Pek çok insan, zihinsel özelliklerin zihinsel olmayan (non-mental) doğal özelliklere bağımlı olarak var olduğu görüşünü tözsel ikici bir görüş benimseyerek kolaylıkla reddedebilirler (Ridge 2007: 337). Bu bağımlılık ilişkisi yani ahlaki özellikler ile diğer özellikler arasındaki ilişki ise zorunlu bir ilişki olarak gözükmektedir.

Ahlaki özellikler-diğer özellikler ilişkisi açısından ikinci gereklilik ise neden belirli doğal özelliklere belirli ahlaki özellikleri yüklemlediğimiz ancak diğer başka doğal özelliklere yüklemlemediğimizin açıklanmasıdır. Bu soruya Shafer-Landau, bir açıklama getirmenin güç olduğunu, bu sorunun yanıtının normatif etik alanındaki araştırmalar ile verilebileceğini belirtir. Ayrıca sonraki makalesinde ahlaki özelliklerin, açıklanamayacak kaba olgular olduğunu kabul etmemiz gerektiğini savunmuştur (Shafer-Landau 2005: 318, 319). Cornell realizm için de geçerli olduğu gibi indirgemeci olmayan meta etik teorilerin zayıf yönlerinden biri budur.

Metaetik alanındaki ahlaki realist görüşlerin yöntemi açısından durumu değerlendirirsek; araştırılan sorun, doğruluğu insanların hepsi veya büyük çoğunluğunca kabul edilen temel bir takım ahlaki önermelerin doğru olup olmadığ değil, bu ahlaki önermelerin doğru olduğu kabul edilerek, bu doğruluğu ilgili ahlaki realist meta etik teorinin açıklamasıdır. Shafer-Landau ise bu görevi birincil dereceden ahlaki sorulara yanıt veren normatif etiğe yüklemiş gözükmektedir ve doyurucu herhangi bir yanıt vermemektedir. Dahası Shafer-Landau'nun sistematik bir ahlaki realizm savunması yaptığını düşünürsek, böyle bir yaklaşım savunduğu realist görüşlerin tersine genel kabul gören ahlaki yükümlülükleri bile tartışmaya açmış gözükmektedir. 
Ahlaki yükümlülüklerin normatifliği konusunda ise Shafer-Landau, ahlaki özelliklerin eylem için kategorik gerekçeler sunacağı görüşünü pratik akılla ilgili diğer seçeneklere karşı savunurken; doğaüstü ahlaki özelliklerin eylem için kategorik gerekçeleri nasıl oluşturabileceklerine ilişkin bağımsız bir argüman sunmamıştır. Soyut nesneler olan ahlaki özellikler ile tümdengelimsel akıl yürütmenin kuralları arasında benzerlik kurar. Ancak daha önce de belirtildiği gibi gerek mantık kurallarının gerekse bunlara benzer doğaüstü özellikler olması durumunda ahlaki özelliklerin eylem için gerekçeler sunabilmesi, insanlara kurallar koyması kişilerin bu kuralların farkında olmaları ve onların bu kuralları kabul etmelerine bağlıdır.

Tümdengelimsel akıl yürütmenin kuralları nesnel olarak var ve ahlaki özelliklerle aralarında kurulan benzerlik doğru olsa bile; tümdengelimsel akıl yürütme kurallarının nesnel olması bu kuralların bütün insanlar arasında yayılmış ve insanlarca yaygın biçimde bilindiğini göstermez. Örneğin çevremizdeki pek çok insanın akıl yürütmede veya günlük konuşmalarında yaptıkları mantık hatalarının pek çok farkında olmadıklarını ve bunların mantık hatası veya mantık kurallarına aykırı olduğunun farkında olmadıklarını söyleyebiliriz. Yani nesnel anlamda tümdengelimsel akıl yürütme kurallarına uymak için insanların hepsinin gerekçeleri olduğunu söyleyemeyiz. $\mathrm{Bu}$ da ahlakın bütün insanlara yayılan bir yapısı olması açısından tümdengelimsel akıl yürütme ile farklılığını göstermektedir.

Soyut nesneler ile ilgili felsefi tartışmalardaki genel kabul, soyut nesnelerin nedensel ilişkiye giremeyen özellikler olarak tanımlanmaları yönündedir (Rosen 2013) ve Shafer-Landau da soyut nesneler olarak ahlaki özelliklerin nedensel ilişkiye girme özelliği olmadığını belirtmiştir. Nedensel ilişkiye giremeyen ve varlığı bütünüyle onları oluşturan doğal özelliklere bağlı olan soyut nesnelerin insanlara eylem için kategorik gerekçeler sunabileceğini söylemek zor gözükmektedir. Dolayısıyla gerek ahlak ile benzerlik kurulan tümdengelimsel akıl yürütme kurallarının nüfuz eden yapıda olmaması gerekse soyut nesnelerin nedensel ilişkiye girme özelliğinin olmaması nedeniyle; ahlaki özelliklerin soyut nesneler benzeri doğaüstü özellikler olması durumunda eylem için kategorik gerekçeler oluşturmayı nasıl başarabileceklerine ilişkin bağımsız bir argümana gereksinim vardır.

Ahlaki bilgi konusunda ise en azından kimi ahlaki özelliklerin başka bir gerekçelendirmeye gereksinim duymadan kendiliğinden doğru ve soyut nesneler oldukları için a priori olarak bilinebilir oldukları belirtilmiştir. Ahlaki yükümlülüklerin normatifliği ile ilgili bölümde belirtildiği gibi a priori bilgi ile ulaşılan soyut nesnelere bütün rasyonel insanların kolayca erişeceğini savunmak için bağımsız bir argüman gerekmektedir ki bu argüman normatiflik açısından da ahlaki doğaüstücülüğü daha güçlü bir konuma getirebilir. Ahlaki özelliklerin a priori olarak bilinebilir olması, ahlakın bütün rasyonel insanlara nüfuz eden yapısını sağlamak için tek başına yeterli gözükmemektedir.

Shafer-Landau, gerek neden belirli ahlaki önermelerin doğru olduğu, gerekse ahlaki özelliklerin nasıl eylem için kategorik gerekçeler sunabileceği gibi sorulara anlamlı açıklamalar sunamamıştır. Bu sorulara anlamlı açıklamalar sunmak yerine ahlak dışındaki herhangi bir alanda da bu tip açıklanması güç durumlar olabileceğini; kimi olguları açıklanamayan kaba olgular olarak kabul etmememiz durumunda yalnızca 
ahlak alanında değil pek çok alanda anti realist bir görüş benimsenmesi gerektiğini savunarak bu sorunları çözmeye çalışmıştır. David Copp'un da belirttiği gibi ShaferLandau'nun yeterli açıklama sunamadığı sorunlardan biri olan ve ahlakı diğer alanlardan ayıran özellik normatifliktir ve bu özellik diğer alanlarda geçerli değildir (Copp 2005, 281). Dolayısıyla, nesnel ahlaki özelliklerle ilgili bu açıklama beklentilerine, nesnel ahlaki özelliklerin açıklanamayan kaba olgular olduğu biçiminde yanıt veren bir meta etik teori yerine; bu sorulara yantlar veren bir ahlak teorisinin yeğlenmesinin daha doğru olduğunu düşünüyorum.

\section{Sonuç}

Sonuç olarak Russ Shafer-Landau'nun ahlaki doğaüstücülüğe ilişkin savunması, Moore'un görüşlerinin de karşılaştığı epistemik ve metafizik eleştirilere yanıt vermekte başarısız gözükmektedir. Shafer-Landau, ahlaki özellikler-diğer özellikler ilişkisi açısından soyut nesneler olan ahlaki özelliklerin doğal özelliklerle arasındaki zorunlu ilişkinin kopmamasının nasıl sağlanacağını açıklamakta başarılı olamamıştır. Çünkü ahlak alanıyla gerek zihin gerekse kimya alanı arasında kurduğu benzerlik sorunu aşmak için yetersizdir. Ayrıca ahlaki özellikler-diğer özellikler ilişkisi açısından neden belirli doğal özelliklere belirli ahlaki özellikleri yüklemlediğimiz dolayısıyla ShaferLandau'nun görüşüne göre neden belirli doğal özelliklerin belirli ahlaki özellikleri oluş̧turduğu sorusuna da yanıt verememiştir.

Ahlaki yükümlülüklerin normatif olma özelliği açısından da ahlaki doğaüstücülük başarılı gözükmemektedir. Shafer-Landau, ahlaki özelliklerin eylem için kategorik gerekçeler sunduğunu savunmasına karşın, doğaüstücü ontoloji içinde soyut nesneler olarak var olan ahlaki özelliklerin bunu nasıl gerçekleşebileceğine ilişkin bağımsız bir argüman ortaya koyamamaktadır.

Ahlaki bilgi açısından ise bilginin kaynağı olarak a priori bilgi sunulmaktadır. Ahlaki doğaüstücü görüşe göre ahlaki özelliklerin ilgili doğal özelliklerce zorunlu olarak oluşturulduğu ve a priori bilgi ile ulaşlabilen soyut nesneler olduğu kabul edilse de; söz konusu ahlaki doğrulara bütün rasyonel insanların nasıl ulaşacağına ilişkin bağımsız bir argüman sunulmuş gözükmemektedir. 


\section{KAYNAKÇA}

COPP, David (2005). "A Skeptical Challenge to Moral Non-Naturalism and A Defense of Constructivist Naturalism", Philosophical Studies, 126(2): 269-283.

FISHER, Andrew (2011). Metaethics: An Introduction, Durham: Acumen.

HURKA, Thomas (2014). "Moore`s Moral Philosophy" Stanford Encyclopedia of Philosophy, Erişim Tarihi: 12.05.2014, (http://stanford.library.usyd.edu.au/entries/moore-moral/).

LEUENBERGER, Stephen (2008). "Supervenience in Metaphysics", Philosophy Compass, 3(4): 749-762.

McMAHAN, Jeff (2000). "Moral Intuition", The Blackwell Guide to Ethical Theory, derl. Hugh LaFollette, ss. 92-110, Oxford: Blackwell. Press.

MILLER, Alexander (2003). An Introduction to Contemporary Metaethics, Oxford: Polity

MOORE, G. E. (1903, 1971). Principia Ethica, Cambridge: Cambridge University Press.

POJMAN, Louis P. ve James FIESER (2012). Ethics: Discovering Right and Wrong, 7. bs., Belmont: Wadsworth Publishing.

RIDGE, Michael (2007). "Anti-Reductionism and Supervenience", Journal of Moral Philosophy, 4(3): 330-348.

RIDGE, Michael (2013). "Moral Non-Naturalism", Stanford Encyclopedia of Philosophy, Erişim Tarihi: 15.12.2013, (http://plato.stanford.edu/entries/moral-non naturalism/).

ROSEN, Gideon (2013). "Abstract Objects", Stanford Encyclopedia of Philosophy, Erişim Tarihi: 15.12.2013, (http://stanford.library.usyd.edu.au/entries/abstract-objects/).

SHAFER-LANDAU, Russ (2003). Moral Realism: A Defence, New York: Oxford University Press.

SHAFER-LANDAU, Russ (2005). "Replies to Critics", Philosophical Studies, 126(2): 313-329.

SHAFER-LANDAU, Russ (2006). "Ethics as Philosophy: A Defense of Ethical NonNaturalism", Metaethics after Moore, derl. Terry Horgan, Mark Timmons, ss. 209-232, New York: Oxford University Press.

STURGEON, Nicholas L. (1988). "Moral Explanations", Essays on Moral Realism, derl. Geoffrey Sayre-McCord, ss. 229-255, New York: Cornell University Press.

WIELENBERG, Erik J. (2009). "In Defense of Non-Natural, Non-Theistic Moral Realism", Faith and Philosophy, 26(1): 23-41.

YÖNEY, Ferhat (2015). “Ahlak Felsefesinde Olgu-Değer Ayrımı ve Nesnelci Ahlaki Realizm Açısından Değerlendirilmesi”, Felsefe Dünyası, 61: 241-268. 
